\title{
Efficiency of biochar, nitrogen addition and microbial agent amendments in remediation of soil properties and microbial community in mine soils
}

\author{
Junqia Kong ${ }^{1}$, Zhibin $\mathrm{He}^{1}$, Chen Longfei ${ }^{1}$, Rong Yang ${ }^{1}$, and Jun $\mathrm{Du}^{1}$ \\ ${ }^{1}$ Northwest Institute of Eco-Environment and Resources
}

March 15, 2021

\begin{abstract}
Lacking of systematic evaluations in soil quality and microbial community recovery after different amendments addition limits optimization of amendments combination in coal mine-soils. We performed a short-term incubation experiment over 12 weeks to assess the effects of three amendments (biochar: C; nitrogen fertilizer at three levels: N-N1 N3; microbial agent at two levels: $\mathrm{M}-\mathrm{M} 1 \sim \mathrm{M} 2$ ) based on $\mathrm{C} / \mathrm{N}$ ratio (regulated by biochar and $\mathrm{N}$ level: 35:1, 25:1, 12.5:1) on soil quality and microbial community in the Qilian Mountains, China. Over the incubation period, soil $\mathrm{pH}$ and $\mathrm{MBC} / \mathrm{MBN}$ were significantly lower than unamended treatment in $\mathrm{N}$ addition and $\mathrm{C}+\mathrm{M}+\mathrm{N}$ treatments, respectively. Soil organic carbon (SOC), total nitrogen (TN), available nitrogen (AN), available phosphorus (AP), available potassium (AK), microbial biomass carbon (MBC) and microbial biomass nitrogen $(\mathrm{MBN})$ contents had a significant increase in all amended treatments $(\mathrm{P}<0.001)$. Higher $\mathrm{AP}, \mathrm{AK}, \mathrm{MBC}$, $\mathrm{MBN}$ and lower MBC/MBN were observed in N2-treated soil(corresponding to $\mathrm{C} / \mathrm{N}$ ratio of 25:1). Meanwhile, N2-treated soil significantly increased species richness and diversity of soil bacterial community $(\mathrm{P}<0.05)$. Principal coordinate analysis further showed that soil bacterial community compositions were significantly separated by N level. C-M-N treatments (especially at N2 and N1 levels) significantly increased the relative abundance $(>1 \%)$ of the bacterial phyla Bacteroidetes and Firmicutes, and decreased the relative abundance of fungal phyla Chytridiomycota $(\mathrm{P}<0.05)$. Redundancy analysis illustrated the importance of soil nutrients in explaining variability in bacteria community composition (74.73\%) than fungal (35.0\%). Our results indicated that $\mathrm{N}$ and $\mathrm{M}$ addition based on biochar can improve soil quality by neutralizing soil $\mathrm{pH}$ and increasing soil nutrient contents, and the appropriate $\mathrm{C} / \mathrm{N}$ ratio (25:1: biochar $+\mathrm{N} 2$-treated soil) can better promote mass, richness and diversity of soil bacterial community. Our study provided a new insight for achieving restoration of damaged habitats by changing microbial structure, diversity and mass by regulating $\mathrm{C} / \mathrm{N}$ ratio of amendments
\end{abstract}

Efficiency of biochar, nitrogen addition and microbial agent amendments in remediation of soil properties andmicrobial community in mine soils

Junqia Kong, ${ }^{\mathrm{a}, \mathrm{b}}$, Zhibin $\mathrm{He}^{\mathrm{a}}$, Longfei Chen ${ }^{\mathrm{a}}$, Rong Yang ${ }^{\mathrm{a}}$, Jun Du ${ }^{\mathrm{a}}$

${ }^{a}$ Linze Inland River Basin Research Station, Chinese Ecosystem Research Network, Key Laboratory of Ecohydrology of Inland River Basin, Northwest Institute of Eco-Environment and Resources, Chinese Academy of Sciences, Lanzhou 730000, China

${ }^{b}$ University of Chinese Academy of Sciences, Beijing 100049, China

\section{Correspondence}

Zhibin He and Longfei Chen, Linze Inland River Basin Research Station, Chinese Ecosystem Research Network, Key Laboratory of Eco-hydrology of Inland River Basin, Northwest Institute of Eco-Environment and Resources, Chinese Academy of Sciences, Lanzhou 730000, China 
E-mail: hzbmail@lzb.ac.cn(HZ); Chenlongfei_mail@163.com(CL)

\begin{abstract}
Lacking of systematic evaluations in soil quality and microbial community recovery after different amendments addition limits optimization of amendments combination in coal mine-soils. We performed a short-term incubation experiment with a varying temperature over 12 weeks to assess the effects of three amendments (biochar: C; nitrogen fertilizer at three levels: N-N1 $\sim$ N3; microbial agent at two levels: M-M1 $\sim \mathrm{M} 2$ ) based on $\mathrm{C} / \mathrm{N}$ ratio (regulated by biochar and $\mathrm{N}$ level: $35: 1,25: 1,12.5: 1$ ) on soil quality and microbial community in the Qilian Mountains, China. Over the incubation period, soil $\mathrm{pH}$ and $\mathrm{MBC} / \mathrm{MBN}$ were significantly lower than unamended treatment in $\mathrm{N}$ addition and $\mathrm{C}+\mathrm{M}+\mathrm{N}$ treatments, respectively. Soil organic carbon (SOC), total nitrogen ( $\mathrm{TN})$, available nitrogen (AN), available phosphorus (AP), available potassium (AK), microbial biomass carbon $(\mathrm{MBC})$ and microbial biomass nitrogen $(\mathrm{MBN})$ contents had a significant increase in all amended treatments $(P<0.001)$. Higher AP, AK, MBC, MBN and lower MBC/MBN were observed in N2-treated soil(corresponding to $\mathrm{C} / \mathrm{N}$ ratio of 25:1). Meanwhile, N2-treated soil significantly increased species richness and diversity of soil bacterial community $(P<0.05)$. Principal coordinate analysis further showed that soil bacterial community compositions were significantly separated by $\mathrm{N}$ level. C-M-N treatments (especially at N2 and N1 levels) significantly increased the relative abundance $(>1 \%)$ of the bacterial phyla Bacteroidetes and Firmicutes, and decreased the relative abundance of fungal phyla Chytridiomycota $(P<0.05)$. Redundancy analysis illustrated the importance of soil nutrients in explaining variability in bacteria community composition (74.73\%) than fungal (35.0\%). Our results indicated that $\mathrm{N}$ and M addition based on biochar can improve soil quality by neutralizing soil $\mathrm{pH}$ and increasing soil nutrient contents in short-term, and the appropriate $\mathrm{C} / \mathrm{N}$ ratio (25:1: biochar $+\mathrm{N} 2$-treated soil) can better promote mass, richness and diversity of soil bacterial community. Our study provided a new insight for achieving restoration of damaged habitats by changing microbial structure, diversity and mass by regulating $\mathrm{C} / \mathrm{N}$ ratio of amendments.
\end{abstract}

Keywords: Mine soil, Biochar, Microbial agent, N fertilizer, C/N ratio, Soil quality, Microbial community

\title{
Introduction
}

Mining activities in mountainous areas alters soil properties, nutrient availability, and microbial activity, posing environmental threats associated with land degradation, water and soil erosion, and loss of biodiversity (Józefowska et al ., 2017; Ahirwal and Maiti, 2018; Garbin et al ., 2018). Effective soil reclamation processes become urgent and arduous tasks aimed at recovery of the destroyed environment to a self-sustaining state in opencast mining areas. An environmentally sustainable method for achieving soil reclamation in mining areas is the use of soil amendments (Asensio et al ., 2013; Zornoza et al., 2013).

The success of amendments in soil reclamation can be evaluated mainly on two aspects: efficient increase in soil nutrients to support vegetation demand, and growth of soil microbial community (Senesi et al ., 2007; Zornoza et al., 2016). However, applications of various amendments lack systematic evaluations of their effectiveness in restoring mining ecosystems, limiting the selection of materials and amendments for soil reclamation and constraining critical improvements in soil quality and the growth of soil microbial biomass in mining areas.

Biochar amendments have been recently widely and successfully used in mine reclamation (Lehmannet al ., 2011; Moreno-Barriga et al ., 2017). Previous studies have reported positive effects on soil quality and health of biochar created through the pyrolysis of organic residues (Lehmannet al ., 2011; Marchetti et al ., 2012). The addition of biochar materials to mine soils can efficiently contribute to the formation of soil organic matter, retention of nutrients, and sequestration of heavy metals; meanwhile, biochar additions tend to alter some soil microbial communities (Grossman et al ., 2010; Zhuet al ., 2017) and stimulate the growth of other microbial communities (Moreno-Barriga et al ., 2017; Li et al ., 2018). These benefits of biochar indicate that biochar can be used in combination with other amendments to enhance positive effects on mining soils. Soil microorganisms play key roles in ecological functioning of ecosystems, including regulating organic matter decomposition and carbon stabilization, and mediating nutrient cycling (Sun et al ., 2016; 
Pan et al ., 2018). However, extreme soil conditions caused by severe mining disturbance usually have a negative influence on the recovery of soil microbial community diversity and mass (de Quadroset al ., 2016). Previous studies of reclaimed mine soils indicated that microbial biomass and diversity may take 5 to 14 years or longer to recover to undisturbed soil levels (Mummey et al ., 2002; Dangiet al ., 2012). Thus, given the importance of soil microbial community to damaged mining habitat, we try to add microbial agents on basis of biochar amendments in order to activate microbial activity. It is important to verify whether the addition of microbial agents combined with biochar can activate soil microbial activity, and may give new insights on how to promote soil microbial recovery in damaged habitats.

Biochar additions to soils can also absorb mineral nitrogen, which can reduce nitrate-nitrogen $\left(\mathrm{NO}_{3}{ }^{-}-\mathrm{N}\right)$ leaching, increase ammonium-nitrogen $\left(\mathrm{NH}_{4}{ }^{+} \mathrm{N}\right)$ retention, and improve the use efficiency of nitrogen fertilizer (Clough et al ., 2013; Ameloot et al ., 2015). Studies have shown that a combined application of biochar and nitrogen fertilizer had significant effects on soil nutrient content, microbial biomass carbon, nitrogen, and crop yields in agricultural lands (Zheng et al ., 2012; Zhuet al ., 2014). However, there are few reports on the combined application of biochar and nitrogen fertilizer in mine soils. In mine soils, the effects of amendments on soil physicochemical properties, microbial biomass and diversity may depend on the adjustment of the $\mathrm{C} / \mathrm{N}$ ratio (Lucas et al ., 2014). In general, low $\mathrm{C} / \mathrm{N}$ ratio of amendments could have inhibitory effects on the activity of microorganisms, including decreasing microbial biomass and metabolites (Treseder, 2008). However, the effects of combined applications of different levels of nitrogen fertilizer and biochar (adjusting $\mathrm{C} / \mathrm{N}$ ratio in soil) on soil microbial biomass and diversity are still unclear in soil reclamation of mining areas. Therefore, to explore the most favorable ratio of combined application of nitrogen fertilizer and biochar for soil microbial biomass and diversity, which can provide scientific basis for the sustainable recovery of soil in mining area.

Qilian Mountains are important ecological security barrier in the western part of China (Du et al ., 2015), and contain abundant hydropower and mineral resources (i.e. iron ore, copper ore, tungsten ore, coal mine). However, the local environment of the Qilian Mountains has been severely damaged due to long-term illegal mining (i.e. unlicensed mining, mining of protected minerals) for economic benefits. The restoration and reconstruction of the damaged ecosystem in Qilian Mountains becomes an important task of environmental protection. However, there are still many difficulties in ecosystem restoration at field level in this area due to high-altitude, complex topography, large soil heterogeneity, cold and changeable climate. Therefore, a short-term laboratory soil incubation experiment close to the local varying temperature can overcome the above difficulties and provide reference and basis for application at different topographical locations with damaged habitats in mining areas.

To relieve soil nutrient impoverishment and restore soil microbial diversity and mass caused by opencast mining in high-altitude areas, soil reclamation was carried out with the addition of different amendments. We aimed to add microbial agents on basis of biochar amendments in order to activate microbial activity, and determine the most favorable $\mathrm{C} / \mathrm{N}$ ratio (combined application of nitrogen fertilizer and biochar) for promoting soil nutrients, microbial diversity and mass, and select the most effective combination of amendments to mining soil by analyzing shifts in soil physicochemical and biological properties. We conducted a short-term laboratory soil incubation experiment with a varying temperature for 12 weeks with 13 combined treatments by three amendments(biochar, nitrogen fertilizer, microbial agent). Our objectives were to: i) Determine dynamics of soil physicochemical properties ( $\mathrm{pH}, \mathrm{EC}$, soil organic carbon, total nitrogen, available nitrogen, available phosphorus, available potassium) over incubation time, ii) Determine the effects of different amendments on microbial biomass (carbon and nitrogen), and composition and diversity of bacterial and fungal community; and iii) Verify which $\mathrm{C} / \mathrm{N}$ ratio adjusted by the combination of biochar and $\mathrm{N}$ level is more suitable for microbial growth.

\section{Materials and methods}

\subsection{Soil sampling}

On August 16, 2020, soil was collected from a tailing slope of an opencast coal mining area in Datan located 
in the Qilian Mountain (SE Gansu province) (36deg50'54" N, 102deg48'05" E, 2650-2660 m), China. The land use type around the sampling area is mainly natural grassland. The area has a typical semiarid and cold temperate climate, with mean temperature of about $16 \mathrm{degC}$ and mean precipitation of about $375 \mathrm{~mm}$ in the growing season (June to September). The soil types is Inceptisol under the USDA Soil

Taxonomy system which characterized by nutrient impoverishment, sandy to sandy loam texture, visible soil horizons and heavy metals content do not exceed the standard. Five plots, $20 \times 20 \mathrm{~m}^{2}$, were randomly located in a tailing slope of an opencast coal mining area, in which five soil samples $(0-30 \mathrm{~cm})$ were collected for each sample plot, for a total of 25 soil samples. All soil samples were thoroughly homogenized into one composite sample and sieved through a $4 \mathrm{~mm}$ sieve to discard coarse fragments prior to incubation experiments. Mine soil properties are shown in Table 1.

\subsection{Amendments used and soil incubation}

Three soil amendments were used for reclamation purposes, including biochar, nitrogen fertilizer, microbial agent. (i) Biochar feedstock was crop residue (maize), which was air-dried for 30 days and then was ground to pass a $2 \mathrm{~mm}$ sieve. Then, the ground residues were pyrolyzed to form biochar in a muffle furnace with an increase at $5 \operatorname{deg} \mathrm{C} \mathrm{min}^{-1}$ to $500 \mathrm{degC}$ for $2 \mathrm{~h}$. Biochar was ground to $250 \mu \mathrm{m}$ for laboratory incubation. Details about biochar amendments are shown in Table 1. (ii) Nitrogen fertilizer was urea (46.67\% N). (iii) Microbial agent (obtained from Beijing Danlu Biotechnology Co., Ltd) was mainly prepared with castor as a carrier. The carrier was placed in a polypropylene plastic bag and sterilized at 121 for $1.5-2 \mathrm{~h}$, and then cooled. Subsequently, the carrier was inoculated with effective microorganism solution, and put it in a 25 incubator for 4-5 d after mixing. Since we aimed to activate the microbial activity in mine soil by addition of microbial agent, thus, we selected the effective bacteria and fungal with a wide range of adaptability in extreme soil environments. The effective bacteria and fungal composition in the microbial agent (sequencing process according to materials and methods 2.4) contained Ascomycota, Basidiomycota, Chytridiomycota, Mortierellomycota and Proteobacteria, Actinobacteria, Bacteroidetes, Gemmatimonadetes (the relative abundance $>1 \%$ ), and its effective amounts are up to $>300$ million $\mathrm{g}^{-1}$.

Biochar (C) was used for substrates in all treatments, and was thoroughly mixed with mine soil at an application rate of $30 \mathrm{~g}$ carbon $\mathrm{kg}^{-1}$ soil, which was similar to the organic carbon content in the natural grassland soil in the sampling area. Based on the desired $\mathrm{C} / \mathrm{N}$ ratios of 35:1, 25:1 and 12.5:1, nitrogen fertilizer $(\mathrm{N})$ was added at three levels of $0.86\left(\mathrm{~N}_{1}\right), 1.2\left(\mathrm{~N}_{2}\right)$, and $2.4\left(\mathrm{~N}_{3}\right) \mathrm{g} \mathrm{N} \mathrm{kg}^{-1}$ soil, respectively. Microbial agents $(\mathrm{M})$ were thoroughly mixed with $20 \mathrm{~g}$ distilled water into mine soil at a dose of $0.4\left(\mathrm{M}_{1}\right)$ and $0.8\left(\mathrm{M}_{2}\right) \mathrm{g} \mathrm{kg}^{-1}$ soil. Thirteen different treatments with three replicates per treatment were applied to the soil samples: C-N $\mathrm{N}_{0}, \mathrm{C}-\mathrm{N}_{1}, \mathrm{C}-\mathrm{N}_{2}, \mathrm{C}-\mathrm{N}_{3} ; \mathrm{C}-\mathrm{M}_{1}-\mathrm{N}_{0}, \mathrm{C}-\mathrm{M}_{1}-\mathrm{N}_{1}, \mathrm{C}-\mathrm{M}_{1}-\mathrm{N}_{2}, \mathrm{C}-\mathrm{M}_{1}-\mathrm{N}_{3} ; \mathrm{C}-\mathrm{M}_{2}-\mathrm{N}_{0}, \mathrm{C}-\mathrm{M}_{2}-\mathrm{N}_{1}$, C- $\mathrm{M}_{2}-\mathrm{N}_{2}, \mathrm{C}-\mathrm{M}_{2}-\mathrm{N}_{3}$, and unamended mine soil was used as control (CK) (Fig.1).

Laboratory incubation was carried out with $1000 \mathrm{~g}$ of mine soil in a $2 \mathrm{~L}$ beaker under aerobic and dark conditions for 90 days in a varying temperature incubator (JYL-253, Jiayu, Shanghai, China), at a constant soil moisture of $50 \%$ of water holding capacity and a varying temperature which gradually increased from 5 to $22^{\circ} \mathrm{C}$ for the first $12 \mathrm{~h}$, and then decreased from 22 to $5^{\circ} \mathrm{C}$ for the last $12 \mathrm{~h}$ (close to the local summer temperature condition). Soils were sampled to monitor $\mathrm{pH}$, soil organic carbon (SOC), total nitrogen (TN), available nitrogen $(\mathrm{AN})$, available phosphorus (AP), available potassium (AK), microbial biomass carbon (MBC) and microbial biomass nitrogen (MBN) at $0,5,12,45,90$ days of incubation with. The first sampling point (day 0) was collected just after soil sampling. To observe the effect of treatment on the structure and diversity of microbial communities, bacterial and fungal communities were assayed at the end of the incubation.

\subsection{Soil physicochemical and microbial biomass analyses}

Amended soil samples were divided into two parts: one part was air dried and shaken on a 2-mm sieves for the measurements of $\mathrm{pH}, \mathrm{SOC}, \mathrm{TN}, \mathrm{AN}, \mathrm{AP}$ and AK. Detailed soil physicochemical analyzes were described in Chen et al . 2020. The other part was stored at $4{ }^{\circ} \mathrm{C}$ in a refrigerator for microbial biomass measurements. 
Soil samples stored at $4{ }^{\circ} \mathrm{C}$ were measured for MBC and MBN using chloroform fumigation and extraction method (Vance et al., 1987). Briefly, $10 \mathrm{~g}$ of oven-dry soil was fumigated with chloroform in the dark for 48 $\mathrm{h}$ after which $\mathrm{C}$ and $\mathrm{N}$ of fumigated and non-fumigated (control) samples was extracted with $0.5 \mathrm{ml} \mathrm{K}_{2} \mathrm{SO}_{4}$, and then total dissolved organic $\mathrm{C}$ was determined on an organic carbon analyzer (Shimadzu Model TOC), while total extractable $\mathrm{N}$ was quantified with a flow-injection instrument. After values in non-fumigated were subtracted from those of fumigated samples, a Kec/Ken factor of 0.45 and 0.54 was applied for MBC both MBN.

\subsection{Microbial Abundance and Community Structure}

\subsubsection{DNA extraction, PCR amplification and sequencing}

Soil biological samples representing different treatments were frozen at $-80{ }^{\circ} \mathrm{C}$ for further DNA analysis. DNA was directly extracted using Power Soil kit 152 (MoBio Laboratories, Carlsbad, CA, USA) following the manufacturer's instructions for specific amplification and high throughput sequencing.

The V3-V4 region of bacterial 16S rRNA gene was amplified by a polymerase chain reaction (PCR) using the primer 341F (5'-CCTAYGGGRBGCASCAG-3') and 806R (5'-GGACTACNNGGGTATCTAAT-3'). PCR reactions were carried out in a $25 \mu \mathrm{l}$ mixture with three replicates per DNA sample, containing $5 \mu \mathrm{l}$ of Q5 reaction buffer $(5 \times), 5 \mu \mathrm{l}$ of Q5 High-Fidelity GC buffer $(5 \times), 0.25 \mu \mathrm{l}$ of Q5 High-Fidelity DNA Polymerase $(5 \mathrm{U} / \mu \mathrm{l}), 2 \mu \mathrm{l}(2.5 \mathrm{mM})$ of dNTPs, $1 \mu \mathrm{l}(10 \mathrm{uM})$ of each Forward and Reverse primers, $2 \mu \mathrm{l}$ of DNA Template, and $8.75 \mu \mathrm{l}$ of dd $\mathrm{H}_{2} \mathrm{O}$. The fungal ITS rRNA genes were amplified with $\operatorname{ITS} 1 \mathrm{~F}\left(5^{\prime}-\right.$ CTTGGTCATTTAGAGGAAGTAA-3')/ITS2R(5'-GCTGCGTTCTTCATCGATGC-3') primers. PCR reactions were carried out in a $25 \mu \mathrm{l}$ mixture with three replicates per DNA sample, containing $2 \mu \mathrm{L}$ of $10 \times$ Buffer, $2 \mu \mathrm{L}$ of $2.5 \mathrm{mM}$ dNTPs, $0.8 \mu \mathrm{L}$ of each Primer $(5 \mu \mathrm{M}), 0.2 \mu \mathrm{L}$ of rTaq Polymerase, and $10 \mathrm{ng}$ Template DNA. PCR amplification was performed under the following cycling conditions: initial denaturation at 98 ${ }^{\circ} \mathrm{C}$ for 2 min, followed by 25 cycles consisting of denaturation at $98{ }^{\circ} \mathrm{C}$ for $15 \mathrm{~s}$, annealing at $55{ }^{\circ} \mathrm{C}$ for $30 \mathrm{~s}$, and extension at $72{ }^{\circ} \mathrm{C}$ for $30 \mathrm{~s}$, with a final extension of $5 \mathrm{~min}$. All PCR amplifications were performed in triplicate and then combined. PCR amplicons were then pooled in equimolar concentrations on a $1 \%$ agarose gel, and purified PCR products were recovered using a Gel Extraction Kit (Omega Bio-tek, Norcross, GA, USA). High-throughput sequencing of the PCR products was performed on an Illumina Miseq platform (Miseq PE250)(Zhang et al ., 2020).

\subsubsection{Sequencing data processing}

Raw sequence data were quality-filtered, and chimera was checked using the QIIME software (version 1.8.0) to remove reads containing more than $10 \%$ unknown nucleotides and reads where fewer than $50 \%$ of all bases had quality values (Q-values) $>20$ (Caporaso et al ., 2010). Operational taxonomic units (OTUs) were clustered with a sequence threshold of $97 \%$ similarity by UPARSE39, and representative sequences of OTUs were picked up simultaneously. The tag sequence with the highest abundance within each cluster was selected as the representative sequence. The taxonomic assignment of $16 \mathrm{~S}$ rRNA sequences was determined using the bacterial SSUrRNA reference database with the Mothur and SILVA (http://www.arb-silva.de/) classifier, and ITS sequences was determined using the Unite reference database (http://unite. ut.ee/index.php) with the Ribosomal Database Project (RDP) classifier at a 97\% level (Edgaret al ., 2011).

\subsection{Statistical analyses}

Significant differences of treatments on soil physicochemical properties, microbial biomass and alpha diversity indices for microbial communities were detected by One-way analysis-of-variance (ANOVA) followed by a least significant difference (LSD) multiple comparison using SPSS version 17.0 (SPSS Inc., Chicago, IL, United States). Meanwhile, in order to visually display significant differences of different treatments on soil physicochemical properties and microbial biomass, we classified thirteen treatments to five treatments for further One-way analysis: CK, C(C-N0), C-N(C-N1, C-N2, C-N3), C-M (C-M1-N0, C-M2-N0), C-M-N(C-M1N1,C-M1-N2,C-M1-N3; C-M2-N1,C-M2-N2,C-M2-N3). Univariate analysis of general linear model (GLM) was used to analyze the interaction of incubation time and treatments. Heatmaps were generated using 
Omicsmart, a dynamic real-time interactive online platform for data analysis(http://www.omicsmart.com). Alpha diversity indexes (including Chao1, Shannon and Simpson) were calculated using QIIME software. According to a Bray-Curtis similarity matrix, principal coordinates analysis (PCoA) was conducted to analyze the overall differences in microbial communities structures among different treatments. In addition, redundancy analysis (RDA) was aimed to assess the effects of soil physicochemical properties and microbial biomass on bacterial and fungal community composition at phylum level and to extract key soil properties driving the variability in bacterial and fungal community composition after addition of amendments.

\section{Results}

3.1 Effect of amendments on soil physicochemical properties

Amended treatments and incubation time had significant effects on physicochemical properties, and with significant interactions between the two factors $(P<0.001)$. During the entire incubation period, soil $\mathrm{pH}$ was significantly lower after addition of $\mathrm{N}$ fertilizer than $\mathrm{CK}$ treatment; a significant increase in SOC, TN, AN, AP, AK contents in all amended treatments than CK treatment (Table 2).

Specifically, pH decreased more in N3 level, ordered by C-M2-N3, C-M1-N3 and C-N3. SOC with higher contents in M2 level, in which C-M2-N0 treatment supported the highest value, followed by C-M2-N2, C-M2-N1, C-M2-N3. TN and AN contents had higher contents in N3 level, ordered by C-N3, C-M2-N3, C-M1-N3 and C-M2-N3, C-M1-N3 C-N3, respectively. N2 level had higher AP and AK contents, in which both C-M2-N2 treatment supported the highest value, followed by C-M1-N2 (Fig. 2). With the increasing incubation time (Fig.2), $\mathrm{pH}$ increased up to day 12 and then decreased during the remaining incubation time (day 12 to 90) in all amended treatments. AN, AP and AK increased significantly in all amended treatments up to day 45, and then decreased during the remaining incubation time (day 45 to 90 ). In addition, there was an increase in SOC and TN contents over the entire incubation time in all amended treatments.

\subsection{Effect of amendments on soil MBC, MBN and MBC/MBN}

Amended treatments and incubation time had significant effects on MBC, MBN $(P<0.001)$ and MBC/MBN $(P<0.01)$, and had no significant interactions between the two factors. During the entire incubation period, $\mathrm{MBC}$ and $\mathrm{MBN}$ in all amended treatments were significantly higher than those in CK treatment, while $\mathrm{MBC} / \mathrm{MBN}$ only in $\mathrm{C}+\mathrm{M}+\mathrm{N}$ treatments were significantly lower than that of CK treatment (Table 2). Specifically, MBC and MBN contents increased significantly after addition of M (in C-M-N and C-M treatments), in which the M2 and $\mathrm{N} 2$ level supported the higher contents. MBC/MBN decreased significantly in $\mathrm{N} 2$ levels $(\mathrm{C}+\mathrm{M} 2+\mathrm{N} 2$ and $\mathrm{C}+\mathrm{M} 1+\mathrm{N} 2)($ Fig.3). With the increasing incubation time (Fig.3), MBC, MBN and $\mathrm{MBC} / \mathrm{MBN}$ in CK treatment remained almost unaltered, and with the average value of $42 \mathrm{mg} / \mathrm{kg}, 5 \mathrm{mg} / \mathrm{kg}$ and 9.52, respectively. MBC and MBN $(P<0.01)$ increased significantly up to day 45 , and then decreasing during the remaining incubation time(day 45 to 90 ). $\mathrm{MBC} / \mathrm{MBN}$ in all amended treatments exhibited significant changes with incubation time but no obvious regularity.

\subsection{Diversity and composition of soil bacterial community}

A total of 1,532,205 bacterial sequences were obtained from the complete data set, of which 13,769 bacterial OTUs belonged to 33 phyla, 257 classes, 257 orders, 475 families and 1,000 genera. The rarefaction curves of bacteria showed clear asymptotes, which indicated a near complete and true sampling of the community. The dominant phyla (relative abundance $>1 \%$ ) were Proteobacteria (48.26-82.32\%), Actinobacteria (16.59$4.09 \%$ ), Bacteroidetes (4.49-15.47\%), Firmicutes (0.55-9.20\%), Gemmatimonadetes (1.76-8.18\%), Chloroflexi (0.89-5.21\%), Patescibacteria (0.87-5.17\%), and Acidobacteria (0.09-2.72\%), together accounting for $>98 \%$ of bacterial sequences across all samples (Fig. S1a). Notably, the relative abundance of Bacteroidetes increased significantly in $\mathrm{C}-\mathrm{M}-\mathrm{N}$ treatments $(P<0.001)$, in which $\mathrm{N} 2$ level increased the higher value (Fig. S1a). Firmicutes also increased significantly in $\mathrm{C}-\mathrm{M}-\mathrm{N}$ treatments $(P<0.01)$, in which $\mathrm{N} 1$ level increased the higher value. However, the relative abundance of Acidobacteria decreased significantly $(P<0.001)$ with addition of $\mathrm{N}$ fertilizer treatments, in which $\mathrm{N} 1$ level (ordered by $\mathrm{C}+\mathrm{N} 1, \mathrm{C}+\mathrm{M} 1+\mathrm{N} 1, \mathrm{C}+\mathrm{M} 2+\mathrm{N} 1$ ) decreased obviously (Table 3 ). 
Alpha-diversity estimated by Chao1 estimator, and Shannon and Simpson indices showed significant differences in species richness and diversity of soil bacterial community between different treatments $(P<0.05)$. Chao1 estimator was significantly higher in $\mathrm{C}(\mathrm{C}-\mathrm{N} 0), \mathrm{C}+\mathrm{M}(\mathrm{C}-\mathrm{M} 1-\mathrm{N} 0, \mathrm{C}-\mathrm{M} 2-\mathrm{N} 0)$ and $\mathrm{C}+\mathrm{M}+\mathrm{N} 2$ (C-N2, C-M1-N2, C-M2-N2) treatments than in CK treatment $(P<0.05)$, in which N2 level treatment supported higher value (highest in C-M2-N2 treatment). Simpson and Shannon indices were significantly higher in all amended treatments especially at the N2 level $(P<0.05)$, but no significant difference observed between amended treatments (Table 4).

PCoA analysis based on Bray-Curtis distances accounted for $47.3 \%$ of total variance among bacterial communities, with axes 1 and 2 explaining 25.4 and $21.9 \%$ of the variance, respectively (Fig. 4a). PCoA analysis showed that bacterial communities were divided into three major groups. Treatments with N1 and N2 level (C-N1, C-N2, C-M1-N1, C-M1-N2, C-M2-N1 and C-M2-N2) tended to group together, N3 level (C-N3, CM1-N3 and C-M2-N3) clustered into another group, and treatments without N addition (C-N0, C-M1-N0, C-M2-N0) grouped together with CK $\left(\mathrm{R}^{2}=0.555>0.5, \mathrm{P}<0.001\right.$; PERMANOVA, Test statistic $=5.0189$, $\mathrm{P}=0.001)$. Overall, three groups exhibited significant differences in bacterial community composition and were separated mainly by $\mathrm{N}$ level.

\subsection{Diversity and composition of soil fungal community}

A total of 2,625,602 fungal sequences were obtained from the complete data set, of which 2,446 fungal OTUs belonged to 12 phyla, 36 classes, 89 orders, 226 families, and 417 genera. The rarefaction curves of fungal showed clear asymptotes, which indicated a near complete and true sampling of the community. The dominant phyla were in the ranking order: Ascomycota (85.66\%-51.53\%), Basidiomycota (31.75\%-1.64\%), unclassified Fungi (18.34\%-3.45\%), unidentified (18.07-2.53\%), and Chytridiomycota (2.93\%-0.01\%), together accounting for $>98 \%$ of fungal sequences across all samples (Fig. S1b). Notably, the relative abundance of Chytridiomycota $(\mathrm{p}<0.05)$ decreased significantly with addition of amendments, in which C-M-N decreased the most. No significant differences were observed in Ascomycota and Basidiomycota (except for unclassified Fungi and unidentified) at all amended treatments, and Ascomycota decreased with the $\mathrm{N}$ addition. Basidiomycota increased after $\mathrm{M}$ addition and decreased in $\mathrm{C}$ and $\mathrm{C}+\mathrm{N}$ treatments(Table 3).

Alpha-diversity estimated by Chao1 estimator, and Shannon indices showed significant differences in species richness and diversity of soil fungal community between different treatment $(P<0.05)$. Chao1 estimator was significantly higher in C (C-N0), C+M2+N (C-M2-N0, C-M2-N1, C-M2-N2, C-M2-N3) treatments in CK $(P<0.05)$, in which M2 level supported higher value (highest in C-M2-N0 treatment). Simpson indices had no significant difference between amended and CK treatment. Shannon indices were significantly higher in $\mathrm{C}+\mathrm{M} 1+\mathrm{N} 2$ and $\mathrm{C}-\mathrm{M} 2-\mathrm{N} 2$ treatment(Table 4).

PCoA analysis based on Bray-Curtis distances accounted for $42.8 \%$ of total variance among the fungal communities, with axes 1 and 2 explaining 23.7 and $19.1 \%$ of the variance, respectively (Fig. 4b). PCoA analysis showed that fungal communities also were divided into three major groups. All M2-level treatments (C-M2-N0, C-M2-N1, C-M2-N2, C-M2-N3) tended to group together, M1 level (C-M1-N0, C-M1-N1, CM1-N2, C-M1-N3) clustered into another group, and treatments without M addition (C-N0, C-N1, C-N2, C-N3) were grouped together with $\mathrm{CK}\left(\mathrm{R}^{2}=0.504>0.5, \mathrm{P}<0.001 ;\right.$ PERMANOVA,Test statistic $=2.203$,P $=0.001)$. Overall, three groups exhibited significant differences in fungal community composition and were separated mainly by M level.

\subsection{Relationships between soil bacterial, fungal community and soil properties}

Redundancy analysis (RDA) depicts the relationships between dominant phyla of soil bacterial and fungal communities and nine selected soil physicochemical properties and microbial biomass (Fig. 5). RDA showed that $\mathrm{pH}\left(\mathrm{r}^{2}=0.91, \mathrm{p}=0.001\right)$, TN $\left(\mathrm{r}^{2}=0.76, \mathrm{p}=0.035\right)$, and MBN $\left(\mathrm{r}^{2}=0.73, \mathrm{p}=0.005\right)$ were the most significant environmental factors explaining variability in bacterial community composition, with the first two axes accounting for 59.57 and $15.16 \%$ of the total variation $(74.73 \%$ ), respectively (Fig. 5a). Proteobacteria, Firmicutes, and Bacteroidetes were negatively correlated with $\mathrm{pH}$ and $\mathrm{MBC} / \mathrm{MBN}$, while significantly positively correlated with other properties; Acidobacteria were negatively correlated with $\mathrm{pH}, \mathrm{TN}$ and AN. RDA 
showed that MBN $\left(\mathrm{r}^{2}=0.84, \mathrm{p}=0.001\right), \mathrm{pH}\left(\mathrm{r}^{2}=0.76, \mathrm{p}=0.001\right), \mathrm{AN}\left(\mathrm{r}^{2}=0.78, \mathrm{p}=0.001\right)$ and $\mathrm{MBC}\left(\mathrm{r}^{2}=0.79\right.$, $\mathrm{p}=0.001$ ) were the most significant environmental factors explaining variability in fungal community composition, with the first two axes accounting for 22.78 and $12.22 \%$ of the total variation (35.0\%), respectively (Fig. 5b). Ascomycota and Chytridiomycota showed a positive correlation with $\mathrm{pH}$ and MBC/MBN, and a negative correlation with other soil properties; Basidiomycota showed a positive correlation with $\mathrm{pH}$, SOC, $\mathrm{MBN}$, and AK.

\section{Discussion}

\subsection{Changes in soil physicochemical properties}

Our results demonstrated that the amended treatments greatly affected soil physicochemical properties. We believed that the change of each soil property was likely to be affected by a single amendment or a combination of amendments that added in our experiment. Differences in soil $\mathrm{pH}$ changes after addition of amendment were likely due to variability in amounts of $\mathrm{N}$ addition. In general, biochar can quickly release alkaline earth metals to increase soil pH (Clough et al ., 2013). In our study, the application of biochar alone did contribute to an increase in soil $\mathrm{pH}$, but no significant increase has been observed. However, we found that soil $\mathrm{pH}$ was significantly lower after $\mathrm{N}$ addition $(P<0.001)$ (especially in N3 level) than in CK treatment over the incubation period. This confirmed that the higher content of $\mathrm{N}$ addition may be an effective method for $\mathrm{pH}$ neutralization in alkaline soils in a certain range, as also observed in other recent studies (Panet al ., 2020; Wang et al ., 2020). The addition of $\mathrm{N}$ fertilizers may lead to decreases in soil $\mathrm{pH}$ due to the oxidation and nitrification of ammonia (Geisseler and Scow, 2014).

We observed a significant increase in SOC contents in all amended treatments than CK treatment over the incubation time. The increased SOC was likely due to the release of high OC contents from biochar into the soil. That biochar increases SOC contents has already been demonstrated in many studies (Agegnehu et al ., 2016; Forjan et al ., 2017). In addition, we found that the addition of microbial agents, especially at high amounts, also lead to a higher increase in SOC contents, indicating that the addition of microbial agents to the mine soil in this study improved SOC contents; this may be attributed to the addition of microbial agents can produce a variety of enzymes (i.e. catalase, peroxidase, urease) by their life activities to promote the synthesis of soil organic matter (Song et al ., 2007). TN also had significant increases in amended treatments, especially in N3 level (highest in C-N3). This result indicated that the increase of TN may originated from high contents of $\mathrm{N}$ addition to mine soil. Subsequently, we subtracted TN contents introduced by $\mathrm{N}$ fertilizer and biochar, and $\mathrm{TN}$ contents was still higher in amended treatments; we attributed this to nitrogen retention in biochar. Phytoavailability of $\mathrm{N}$ is pivotal for soil quality, and low $\mathrm{N}$ contents often represent an immediate limitation to plant growth (Christensen and Schjonning, 2004). In our study, a significant increase in AN contents in all amended treatments than CK treatment similar to TN, and the increase was most obvious at the N3 level (especially in C-M2-N3 treatment). The first reason may be the higher contents of $\mathrm{N}$ fertilizer addition and $\mathrm{N}$ contents contained in the biochar itself. Another possible reason could be that higher microbial activity due to the addition of $\mathrm{M}$ contributed to $\mathrm{N}$ mineralization and increased AN content (Ahirwal and Maiti, 2018).

$\mathrm{AP}$ and $\mathrm{AK}$ also showed a significant increase in all amended treatments, also exhibited higher contents both at the N2 level (ordered by C-M2-N2, C-M1-N2, C-N2 treatments), showing AP and AK increased with increasing $\mathrm{M}$ contents in N2 level. Studies have shown that the addition of biochar can increase AP contents in soils because biochar itself contains large amounts of $\mathrm{P}$ with higher effectiveness (Agegnehu et al ., 2016; Rafael et al ., 2020). Meanwhile, we found AP and AK contents increased with increasing M contents in $\mathrm{N} 2$ level. A possible explanation for this is that the higher contents of $\mathrm{M}$ added into the soil can reduce the fixation of $\mathrm{P}, \mathrm{K}$ and improve the availability of soil $\mathrm{P}$ and $\mathrm{K}$; also, the number of soil microorganisms after the higher contents of $\mathrm{M}$ addition increased significantly, which promoted the mineralization of $\mathrm{P}$ and the conversion of organophosphorus to AP due to the release of $\mathrm{P}$ affected by bacteria (i.e. Bacillus subtilis) (Hu et al ., 2009). More importantly, AP and AK exhibited higher contents in N2 levels, which may be an appropriate amount of $\mathrm{N}$ input for $\mathrm{N}$ sources for microorganisms, promoting microbial activity, and subsequently promoting the activation and decomposition of insoluble substances in the soil. Above all, 
relatively higher contents of $\mathrm{N}$ and $\mathrm{M}$ addition based on biochar in the short-term can improve soil quality by neutralizing soil $\mathrm{pH}$ and increasing soil nutrient content.

\subsection{Changes in soil MBC, MBN and MBC/MBN}

Our results demonstrated that $\mathrm{MBC}$ and $\mathrm{MBN}$ had a significant increase in amended treatments over the incubation period. In general, the variability in MBC and MBN after amendment addition was first affected by the characteristics of biochar. Biochar, with its extensive surface area and a porous structure, can better coordinate soil water, fertilizer, air and heat, providing an excellent environment for the growth and reproduction of microorganisms(Clough et al ., 2013); also, the surface of biochar has a high density of negative charge that adsorbs substances toxic to microorganisms, thereby promoting their growth and reproduction, and increasing microbial biomass (Ok et al ., 2015). This also explains why higher contents of $\mathrm{M}$ contributed to further increase in MBC and MBN. However, our study showed that MBC and MBN increased up to day 45 , and then decreased during the remaining incubation time; this indicated that microorganisms started growing in the presence of easily-available organic substrates (de Mora et al ., 2005), which were rapidly depleted or stabilized after 45 days. This suggested that biochar did not have the capacity to provide additional substrates for microbial growth, and microorganisms could not achieve continuous increase in this mine soil; in turn, we also confirmed that the addition of $\mathrm{M}$ was essential for soil microbial growth (also shown by beta diversity of fungi). In addition, soil microbial growth was not only affected by carbon sources, but also regulated by $\mathrm{N}$ fertilizers. In our study, MBC and MBN contents were higher in N2 level, in which C-M2-N2 supported highest value, indicating that biochar $+\mathrm{N}$ at $1.2 \mathrm{~g} \mathrm{~N} \mathrm{~kg}^{-1}$ soil+ microbial agents at 0.8 $\mathrm{g} \mathrm{kg}^{-1}$ (corresponding to $\mathrm{C} / \mathrm{N}$ ratio of 25:1) could satisfy microbial nitrogen demand and contribute to the increase of soil microbial biomass. However, low $\mathrm{N}$ and abundant $\mathrm{C}(\mathrm{C} / \mathrm{N}$ ratio of 35:1) may reduce soil microbial biomass.

The level of soil MBC/MBN ratio can reflect the supply capacity of soil nitrogen. A small value of MBC/MBN with high bioavailability of nitrogen can improve the utilization rate of soil $\mathrm{N}$ (Liang et al ., 2006). In our study, the average value of $\mathrm{MBC} / \mathrm{MBN}$ ratio in all amended treatments was significantly lower than that of the CK treatment, indicating that the combination of amendments could effectively improve the utilization rate of nitrogen. Furthermore, $\mathrm{MBC} / \mathrm{MBN}$ ratio decreased significantly in N2 levels, in which $\mathrm{C}+\mathrm{M} 2+\mathrm{N} 2$ with the lowest $\mathrm{MBC} / \mathrm{MBN}$ ratio. This may be due to the biological activity of $\mathrm{N}$ increasing in the combination of biochar and $\mathrm{N}$ fertilizer at this level; as a result, more nitrogen can be assimilated by the microorganisms, which increases the contents of MBN, resulting in a decrease in the MBC/MBN ratio. It is also possible that the combination of biochar and $\mathrm{N} 2$ level is more conducive to the growth and reproduction of bacteria, which increases the proportion of bacteria in soil microbial community, and causes a decrease in $\mathrm{MBC} / \mathrm{MBN}$ ratio due to smaller MBC/MBN ratio in bacteria than fungi (Tao et al. , 2016). Overall, our results confirmed proper $\mathrm{C} / \mathrm{N}$ ratio of $25: 1$ (corresponding to biochar $+\mathrm{N}$ fertilizer at $1.2 \mathrm{~g} \mathrm{~N}$ $\mathrm{kg}^{-1}$ soil + microbial agent at $0.8 \mathrm{~g} \mathrm{~kg}^{-1}$ ) could contribute to the increase of microbial biomass and effectively improve the utilization rate of soil $\mathrm{N}$ in short-term.

\subsection{Changes in soil bacterial and fungal community composition and structure}

The restoration of microbial diversity is a key issue in reclaimed soil systems (Lucas et al ., 2014). After a 90day incubation, bacterial co-ordinated alpha and beta diversity were affected by the amendments. The Chao1 estimator of alpha diversity revealed a higher bacterial than fungal species richness in mine soils. Meanwhile, Chao1 estimator of bacterial was significantly higher in $\mathrm{N} 2$ level, indicating that proper $\mathrm{N}$ addition based on biochar (corresponding to $\mathrm{C} / \mathrm{N}$ ratio of 25:1) promoted the restoration of species richness of soil bacterial community. However, Chao1 estimator of fungal was significantly higher in M2 level, indicating that higher $\mathrm{M}$ addition promoted the restoration of species richness of soil fungal community. We also observed that bacterial alpha-diversity (represented by Simpson indices) in all amended treatments (especially in N2 level) increased significantly compared with CK treatment, while no significant increase was recorded for in soil fungal community, indicating that amended treatments promoted the restoration of species diversity of soil bacterial community, but were not sufficient for increasing that species diversity of soil fungal community. 
Beta diversity further indicated that the bacterial community composition formed three separate clusters based on $\mathrm{N}$ level, while the fungal community composition was mainly separated by $\mathrm{M}$ addition. This indicated that the $\mathrm{N}$ level may be a key driving factor behind the positive influence of biochar on bacterial community composition. A possible reason is that the composition of soil bacterial community may be regulated by $\mathrm{C} / \mathrm{N}$ ratio in the combined $\mathrm{N}$ level and biochar. However, composition of the microbial agent itself may also affect clusters of fungal communities, indicating that fungal community composition was not regulated by biochar and $\mathrm{N}$ but by microbial agent in this study. This finding may attribute to fungi have higher soil nutrient level requirements than we provided by biochar and $\mathrm{N}$ fertilizer compared with bacteria (Niu et al ., 2015). The addition of microbial agent affected the composition of soil fungal community, but further studies are needed to confirm this result. Meanwhile, our study also revealed that soil physicochemical properties and microbial biomass together explained a larger proportion of variation in bacterial communities $(74.73 \%)$ than in fungal communities (35\%). This result further confirmed that soil bacteria are highly sensitive to the changes in soil nutrients (Yao et al ., 2014).

In this study, high-throughput sequencing revealed significant changes in soil bacterial community structure due to the application of amendments at the end of the incubation. The Proteobacteria phyla dominated soil bacterial communities across all soil samples, which was consistent with predominant microbiota found in the mining area in a previous study (Kolton et al ., 2011; Narendrula-Kotha and Nkongolo, 2016). This may be related to the extensive degradation properties of Proteobacteria and their ability to inhabit a wide range of habitats (Hanna et al ., 2013). At the same time, in our study, the increase over control in the abundances of Proteobacteria phyla after addition of amendments may be due to fast growth rates when levels of available substrates are high (Zhang et al ., 2016; Su et al ., 2017; Wang et al ., 2017). Moreover, Fig.5 a also showed that the accumulation of soil nutrients provided resources for the survival of Proteobacteria (Fiereret al ., 2007). We also found that the relative abundance of Bacteroidetes $(P<0.001)$ and Firmicutes $(P<0.01)$ increased significantly in C-M-N treatments, especially in N2 and N1 treatments, respectively. Bactericide have fast growth rates and are more likely to grow in eutrophic conditions (Willet al ., 2010), which explains the increase in Bacteroidetes in C-M-N treatments. Firmicutes have the ability to secrete enzymes that are key to the nitrogen fixation pathway and are directly involved in various other nitrogen metabolism functions such as nitrate reduction, dissimilatory nitrate reduction, and denitrification (Ren, 2018); thus, Firmicutes are considered to have the potential to promote nitrogen cycling after addition proper amounts of $\mathrm{N}$ fertilizer like $\mathrm{N} 1$ level in our study. In addition, the relative abundance of Acidobacteria decreased significantly with addition of $\mathrm{N}$ fertilizer. The result of RDA also confirmed that the abundance of Acidobacteria was negatively related to TN (Fig.6a). Acidobacteria are generally classified as slow-growing oligotrophs (Fierer et al ., 2007; Wang et al ., 2020), and their abundances usually decrease with $\mathrm{N}$ fertilizer application (Francioli et al ., 2016).

Overall, the relative abundance of Bacteroidetes $(P<0.001)$, Firmicutes $(P<0.01)$ and Acidobacteria $(P$ $<0.001$ ), changed significantly after proper $\mathrm{N}$ addition especially N1 and N2 level (corresponding to $\mathrm{C} / \mathrm{N}$ ratio of 35 and 25:1), indicating that proper $\mathrm{C} / \mathrm{N}$ ratio (35 and 25:1) has a significant effect on the relative abundance of these three bacteria.

The dominant fungal phylum in this study was Ascomycota, corresponding to findings of previous studies in mining soils. Also, the relative abundance of Ascomycota phyla decreased with the addition of $\mathrm{N}$ fertilizer but not significantly. This decrease was likely due to preferred habitat of Ascomycota, which are particularly important under conditions of low $\mathrm{N}$ availability, and decline with increased $\mathrm{N}$ availability (Beimforde $e t$ al ., 2014; Yuet al ., 2020) in agreement with the negative correlation betweenAscomycota and TN (Fig.5b). Notably, the relative abundance of Chytridiomycota $(\mathrm{p}<0.05)$ decreased significantly at all amended treatments, which may be due to a more sensitive response of Chytridiomycota to changes in soil acidity and nutrient availability. However, the $\mathrm{pH}$ was still alkaline in our experiment although it was neutralized after amendments addition. The relative abundance of Basidiomycota, a decomposer of glucose and cellulose, increased after $\mathrm{M}$ addition, and decreased in $\mathrm{C}$ and $\mathrm{C}+\mathrm{N}$ treatment. This may be related to the addition of $\mathrm{M}$ which can promote the metabolism of recalcitrant organic carbon by Basidiomycota (Yanget al ., 2019). In summary, soil properties (especially related to $\mathrm{N}$ ), played an important role in shaping fungal community 
composition.

\section{Conclusions}

This work is one of the first attempts to determine the effects of three amendments (biochar, $\mathrm{N}$ fertilizer, microbial agent) based on $\mathrm{C} / \mathrm{N}$ ratio( regulated by biochar and three $\mathrm{N}$ level) on soil quality and soil microbial structure and diversity. Our results showed relatively higher contents of $\mathrm{N}$ and $\mathrm{M}$ addition based on biochar in the short-term can improve soil quality by neutralizing soil $\mathrm{pH}$ and increasing soil nutrient content. N2treated soil (corresponding to $\mathrm{C} / \mathrm{N}$ ratio of $25: 1$ ) could contribute to the increase of microbial biomass and effectively improve the utilization rate of soil $\mathrm{N}$.

N2-treated soil combined with biochar and the microbial agent could significantly promote the restoration of species richness and diversity of soil bacterial community; meanwhile, PCoA further indicated that the $\mathrm{N}$ level (corresponding to $\mathrm{C} / \mathrm{N}$ ratio) may be a key driving factor behind the positive influence of biochar on bacterial community composition. $\mathrm{N} 2$ and N1-treated soil (C/N ratio of 25 and 12.5:1) has a significant effect on the relative abundance of Bacteroidetes, Firmicutes and Acidobacteria. M2-treated soil could promote the restoration of species richness of soil fungal community, PCoA further indicated that fungal community composition was regulated by $\mathrm{M}$ addition in this study. In addition, RDA analysis indicated that soil bacteria are highly sensitive to the changes in soil nutrients than fungal. Overall, our study provided a new idea for changing soil microbial community by regulating $\mathrm{C} / \mathrm{N}$ ratio by amendments to achieve restoration of damaged habitats, which provided a basis for field application to land managers at this coal mine in Qilian mountains.

\section{Acknowledgments}

This work was jointly supported by Science and Technology Service Network Initiative of the Chinese Academy of Sciences (KFJ-STS-QYZD-175), the Strategic Priority Research Program of the Chinese Academy of Sciences (XDA23060301), the National Key Research and Development Program of China (No. 2019YFC0507403). The authors thank the editors and anonymous reviewers for their valuable comments and suggestions on this manuscript.

\section{Conflict of interest}

The authors declare that they have no conflict of interest.

\section{Data Accessibility Statement}

All data are available in the Dryad Data Repository

\section{References}

Agegnehu, G., Bass, A.M., Nelson, P.N., Bird, M.I. (2016). Benefits of biochar, compost and biochar-compost for soil quality, maize yield and greenhouse gas emissions in a tropical agricultural soil. Science of the Total Environment, 543, 295-306.

Ahirwal, J., Maiti, S.K. (2018). Development of Technosol properties and recovery of carbon stock after 16 years of revegetation on coal mine degraded lands, India. Catena, 166, 114-123.

Ameloot, N., Sleutel, S., Das, K., Kanagaratnam, J., De Neve, S. (2015). Biochar amendment to soils with contrasting organic matter level: effects on $\mathrm{N}$ mineralization and biological soil properties. Global Change Biology Bioenergy, 7, 135-144.

Asensio, V., Covelo, E.F., Kandeler, E. (2013). Soil management of copper mine tailing soils-sludge amendment and tree vegetation could improve biological soil quality. Science of the Total Environment, 456, 82-90.

Beimforde, C., Feldberg, K., Nylinder, S., Rikkinen, J., Tuovila, H., Dorfelt, H., Gube, M., Jackson, D.J., Reitner, J., Seyfullah, L. (2014). Estimating the Phanerozoic history of the Ascomycota lineages: combining fossil and molecular data. Molecular Phylogenetics Evolution, 78, 386-398. 
Caporaso, J.G., Kuczynski, J., Stombaugh, J., Bittinger, K., Bushman, F. D., Costello, E. K., Fierer, N., Pena, A.G., Goodrich, J.K., Gordon, J.I., Huttley, G.A., Kelley, S.T., Knights, D., Koenig, J.E., Ley, I.E., Lozupone ,C.A., McDonald, D., Muegge, B.D., Pirrung, M., Reeder, J., Sevinsky, J.R., Turnbaugh, P.J., Walters, W.A., Widmann, J., Yatsunenko, T., Zaneveld, J., Knigh, R. (2010). QIIME allows analysis of high-throughput community sequencing data. Nature Methods, 7, 335-336.

Chen, L., He, Z., Zhao, W., Liu, J., Zhou, H., Li, J., Meng, Y., Wang, L. (2020). Soil structure and nutrient supply drive changes in soil microbial communities during conversion of virgin desert soil to irrigated cropland. European Journal Soil Science, 71, 768-781

Christensen, B., Schjonning, P. (2004). Tightening the nitrogen cycle. Managing soil quality: Challenges in Modern Agriculture, 47-67.

Clough, T.J., Condron, L.M., Kammann, C., Muller, C. (2013). A review of biochar and soil nitrogen dynamics. Agronomy, 3, 275-293.

Dangi, S.R., Stahl, P.D., Wick, A.F., Ingram, L.J., Buyer, J.S. (2012). Soil microbial community recovery in reclaimed soils on a surface coal mine site. Soil Science Society of America Journal, 76, 915-924.

de Mora, A.P., Alfredo, Ortega-Calvo, J.J., Cabrera, F., Madejon, E. (2005). Changes in enzyme activities and microbial biomass after "in situ" remediation of a heavy metal-contaminated soil. Applied Soil Ecology, $28,125-137$.

de Quadros, P. D., Zhalnina, K., Davis-Richardson, A. G., Drew, J. C., Menezes, F. B., Flavio, A. D. O., Triplett, E. W. (2016). Coal mining practices reduce the microbial biomass, richness and diversity of soil. Applied Soil Ecology, 98, 195-203.

Du, J., He, Z., Chen, L., Yang, J., Zhu, X., Zhao, W. (2015). Integrating lidar with Landsat data for subalpine temperate forest aboveground carbon estimation. International Journal of Remote Sensing, 36, 5767-5789.

Edgar, R.C., Haas, B.J., Clemente, J.C., Quince, C., Knight, R. (2011). UCHIME improves sensitivity and speed of chimera detection. Bioinformatics, 27, 2194-2200.

Fierer, N., Bradford, M.A., Jackson, R.B. (2007). Toward an ecological classification of soil bacteria. Ecology, 88, 1354-1364.

Forjan, R., Rodriguez-Vila, A., Cerqueira, B., Covelo, E.F. (2017). Comparison of the effects of compost versus compost and biochar on the recovery of a mine soil by improving the nutrient content. Journal of Geochemical Exploration, 183, 46-57.

Francioli, D., Schulz, E., Lentendu, G., Wubet, T., Buscot, F., Reitz, T. (2016). Mineral vs. organic amendments: microbial community structure, activity and abundance of agriculturally relevant microbes are driven by long-term fertilization strategies. Frontiers in Microbiology, 7, 1446.

Garbin, M. L., Misaki, F., Ferreira, P. F., Guidoni-Martins, K. G., Soares, R. B., Mariotte, P., Silva, A. G. (2018). Long-term regeneration of a tropical plant community after sand mining. Ecology and Evolution, 8, $5712-5723$.

Grossman, J.M., O’Neill, B.E., Tsai, S.M., Liang, B., Neves, E., Lehmann, J., Thies, J.E. (2010) Amazonian anthrosols support similar microbial communities that differ distinctly from those extant in adjacent, unmodified soils of the same mineralogy. Microbial Ecology, 60, 192-205.

Geisseler, D., Scow, K.M. (2014). Long-term effects of mineral fertilizers on soil microorganisms-a review. Soil Biol Biochem 75, 54-63

Hanna, S., Kaarina, L., Sihvonen, L.M., Kaarina, S., Mirja, L., Matias, R., Lars, P., Christina, L., Vishal, S. (2013). Bacteria Contribute to Sediment Nutrient Release and Reflect Progressed Eutrophication-Driven Hypoxia in an Organic-Rich Continental Sea. PLOS ONE, 8, e67061. 
Hu, J., Lin, X., Wang, J., Chu, H., Yin, R., Zhang, J. (2009). Population size and specific potential of P-mineralizing and-solubilizing bacteria under long-term P-deficiency fertilization in a sandy loam soil. Pedobiologia, 53, 49-58.

Jozefowska, A., Pietrzykowski, M., Woś, B., Cajthaml, T., Frouz, J. (2017). The effects of tree species and substrate on carbon sequestration and chemical and biological properties in reforested post-mining soils. Geoderma, 292, 9-16.

Kolton, M., Harel, Y.M., Pasternak, Z., Graber, E.R., Elad, Y., Cytryn, E. (2011). Impact of Biochar Application to Soil on the Root-Associated Bacterial Community Structure of Fully Developed Greenhouse Pepper Plants. Applied Environmental Microbiology, 77, 4924-4930.

Liang, B., Lehmann, J., Solomon, D., Kinyangi, J., Grossman, J., O"Neill, B., Skjemstad, J.O., Thies, J., Luizao, F.J., Petersen, J., Neves, E.G. (2006). Black carbon increases cation exchange capacity in soils. Soil Science Society of America Journal, 70, 1719-1730.

Lehmann, J., Rillig, M.C., Thies, J., Masiello, C.A., Hockaday, W.C., Crowley, D. (2011). Biochar effects on soil biota-a review. Soil Biology \& Biochemistry, 43, 1812-1836.

Li, Q., Lei, Z., Song, X., Zhang, Z., Ying, Y., Peng, C. (2018). Biochar amendment decreases soil microbial biomass and increases bacterial diversity in Moso bamboo (Phyllostachys edulis) plantations under simulated nitrogen deposition. Environmental Research Letters, 13, 044029.

Lucas, S.T., D'Angelo, E.M., Williams, M.A. (2014). Improving soil structure by promoting fungal abundance with organic soil amendments. Applied Soil Ecology, 75, 13-23.

Marchetti, R., Castelli, F., Orsi, A., Sghedoni, L., Bochicchio, D. (2012). Biochar from swine manure solids: influence on carbon sequestration and Olsen phosphorus and mineral nitrogen dynamics in soil with and without digestate incorporation. Italian Journal of Agronomy, 7, e26.

Moreno-Barriga, F., Díaz, V., Acosta, J.A., Muñoz, M.Á., Faz, Á., Zornoza, R. (2017). Organic matter dynamics, soil aggregation and microbial biomass and activity in Technosols created with metalliferous mine residues, biochar and marble waste. Geoderma, 301, 19-29.

Mummey, D.L., Stahl, P.D., Buyer, J.S. (2002). Microbial biomarkers as an indicator of ecosystem recovery following surface mine reclamation. Applied Soil Ecology, 21, 251-259.

Narendrula-Kotha, R., Nkongolo, K.K. (2016). Bacterial and fungal community structure and diversity in a mining region under long-term metal exposure revealed by metagenomics sequencing. Ecological Genetics Genomics, 2, 13-24.

Niu, X., Sun, X., Chen, D., Zhang, S. (2015). Soil microorganisms, nutrients and enzyme activity of Larix kaempferi plantation under different ages in mountainous region of eastern Liaoning Province, China. Chin. Chinese Journal of Applied Ecology, 26, 2663-2672.

Ok, Y.S., Uchimiya, S.M., Chang, S.X., Bolan, N. (2015). Biochar: Production, characterization, and applications. Applied Materials \& Interfaces, 5, 10920-10925.

Pan, H., Chen, M., Feng, H., Wei, M., Song, F., Lou, Y., Cui, X., Wang, H., Zhuge, Y. (2020). Organic and inorganic fertilizers respectively drive bacterial and fungal community compositions in a fluvo-aquic soil in northern China. Soil \& Tillage Research, 198, 104540.

Pan, H., Ying, S., Liu, H., Zeng, L., Zhang, Q., Liu, Y., Xu, J., Li, Y., Di, H. (2018). Microbial pathways for nitrous oxide emissions from sheep urine and dung in a typical steppe grassland. Biology Fertility of Soils, $54,717-730$.

Ren, M. (2018). Microbial Community Structure and Its Role in Carbon and Nitrogen Cycle in Tarim Basin. PhD Thesis. Wuhan: Huazhong Agricultural University (in Chinese). 
Senesi, N., Plaza, C., Brunetti, G., Polo, A. (2007). A comparative survey of recent results on humic-like fractions in organic amendments and effects on native soil humic substances. Soil Biology \& Biochemistry, $39,1244-1262$.

Song, C., Li, C., Xu, J., Zheng, L., Li, C.,Wang, W. (2007). Correlations of soil enzyme activity and microbes, nutrients in soil of Jujube orchard in coastal saline land. Scientia Silvae Sinicae 43: 28-32 (in Chinese).

Su, P., Lou, J., Brookes, P.C., Luo, Y., He, Y., Xu, J. (2017). Taxon-specific responses of soil microbial communities to different soil priming effects induced by addition of plant residues and their biochars. Journal of Soils Sediments, 17, 674-684.

Sun, L., Xun, W., Huang, T., Zhang, G., Gao, J., Ran, W., Li, D., Shen, Q., Zhang, R. (2016). Alteration of the soil bacterial community during parent material maturation driven by different fertilization treatments. Soil Biology \& Biochemistry, 96, 207-215.

Treseder, K.K. (2008). Nitrogen additions and microbial biomass: A meta-analysis of ecosystem studies. Ecology Letters, 11, 1111-1120.

Tao, P., Chen, X., Jin, Z., Li, Q., Huang, Q., Zhang, J. (2016). Effects of biochar combined with nitrogen fertilizers on microbial biomass $\mathrm{C}, \mathrm{N}$ and $\mathrm{C}$ to $\mathrm{N}$ ratio of upland red soil. Journal of Soil and Water Conservation, 30, 231-235(in Chinese).

Vance, E.D., Brookes, P.C., Jenkinson, D.S. (1987). An extraction method for measuring soil microbial biomass C. Soil Biology \& Biochemistry, 19, 703-707.

Wang, J., Song, Y., Ma, T., Raza, W., Li, J., Howland, J.G., Huang, Q., Shen, Q. (2017). Impacts of inorganic and organic fertilization treatments on bacterial and fungal communities in a paddy soil. Applied Soil Ecology, 112, 42-50.

Wang, X., Li, Y., Wei, Y., Meng, H., Cao, Y., Lead, J., Hong, J. (2020). Effects of fertilization and reclamation time on soil bacterial communities in coal mining subsidence areas. Science of The Total Environment, 139882 .

Will, C., Thurmer, A., Wollherr, A., Nacke, H., Herold, N., Schrumpf, M., Gutknecht, J., Wubet, T., Buscot, F., Daniel, R. (2010). Horizon-specific bacterial community composition of German grassland soils, as revealed by pyrosequencing-based analysis of $16 \mathrm{~S}$ rRNA genes. Applied Environmental Microbiology, 76, 6751-6759.

Yang, L., Yang, Y., Fei, S., Dong, T., Zeng, Y., Gang, Y., Zhang, Y., Deng, S. (2019). Partitioning biochar properties to elucidate their contributions to bacterial and fungal community composition of purple soil. Science of the Total Environment, 648, 1333-1341.

Yao, M., Rui, J., Li, J., Dai, Y., Bai, Y., Heděnec, P., Wang, J., Zhang, S., Pei, K., Liu, C. (2014). Rate-specific responses of prokaryotic diversity and structure to nitrogen deposition in the Leymus chinensis steppe. Soil Biology \& Biochemistry, 79, 81-90.

Yu, J., Liu, F., Tripathi, B.M., Steinberger, Y. (2020). Changes in the composition of soil bacterial and fungal communities after revegetation with Caragana microphylla in a desertified semiarid grassland. Journal of Arid Environments, 182, 104262.

Zhang, C., Liu, G., Xue, S., Wang, G. (2016). Soil bacterial community dynamics reflect changes in plant community and soil properties during the secondary succession of abandoned farmland in the Loess Plateau. Soil Biology \& Biochemistry, 97, 40-49.

Zhang, S., Shu, J., Xue, H., Zhang, W., Wang, H. (2020). The gut microbiota in Camellia weevils are influenced by plant secondary metabolites and contribute to saponin degradation. mSystems, 5: e00692-19.

Zheng, J., Stewart, C.E., Cotrufo, M.F. (2012). Biochar and nitrogen fertilizer alters soil nitrogen dynamics and greenhouse gas fluxes from two temperate soils. Journal of Environmental Quality, 41, 1361-1370. 
Zhu, Q., Peng, X., Huang, T., Xie, Z., Holden, N.M. (2014). Effect of biochar addition on maize growth and nitrogen use efficiency in acidic red soils. Pedosphere, 24, 699-708.

Zornoza, R., Acosta, J., Faz, A., Bååth, E. (2016). Microbial growth and community structure in acid mine soils after addition of different amendments for soil reclamation. Geoderma, 272, 64-72.

Zornoza, R., Faz, Á., Carmona, D.M., Acosta, J.A., Martínez-Martínez, S., de Vreng, A. (2013). Carbon mineralization, microbial activity and metal dynamics in tailing ponds amended with pig slurry and marble waste. Chemosphere, 90, 2606-2613.

\section{Figure list}

Fig.1 Soil reclamation treatments used for laboratory incubation. Red represents microbial agent levels; White represents nitrogen fertilizer levels; Light brown represents mine soil (reference); Brown represents mine soil with biochar

Fig. 2 Heatmap analysis of the relationships between soil physicochemical properties and incubation time in different amended treatments

Fig. 3 Heatmap analysis of the relationships between soil microbial biomass and incubation time in different amended treatments

Fig.4 Principal coordinate analysis (PCoA) of bacterial (a) and fungal (b) community composition based on Bray-Curtis distances. Values at axes 1 and 2 are the percentages that can be explained by the corresponding axis

Fig. 5 Redundancy analysis (RDA) identifying the relationships between bacterial (a) and fungal (b) phyla and soil properties in different treatments. Values at axes 1 and 2 are the percentages explained by the corresponding axis

Fig.1 Soil reclamation treatments used for laboratory incubation. Red represents microbial agent levels; White represents nitrogen fertilizer levels; Light brown represents mine soil (reference); Brown represents mine soil with biochar
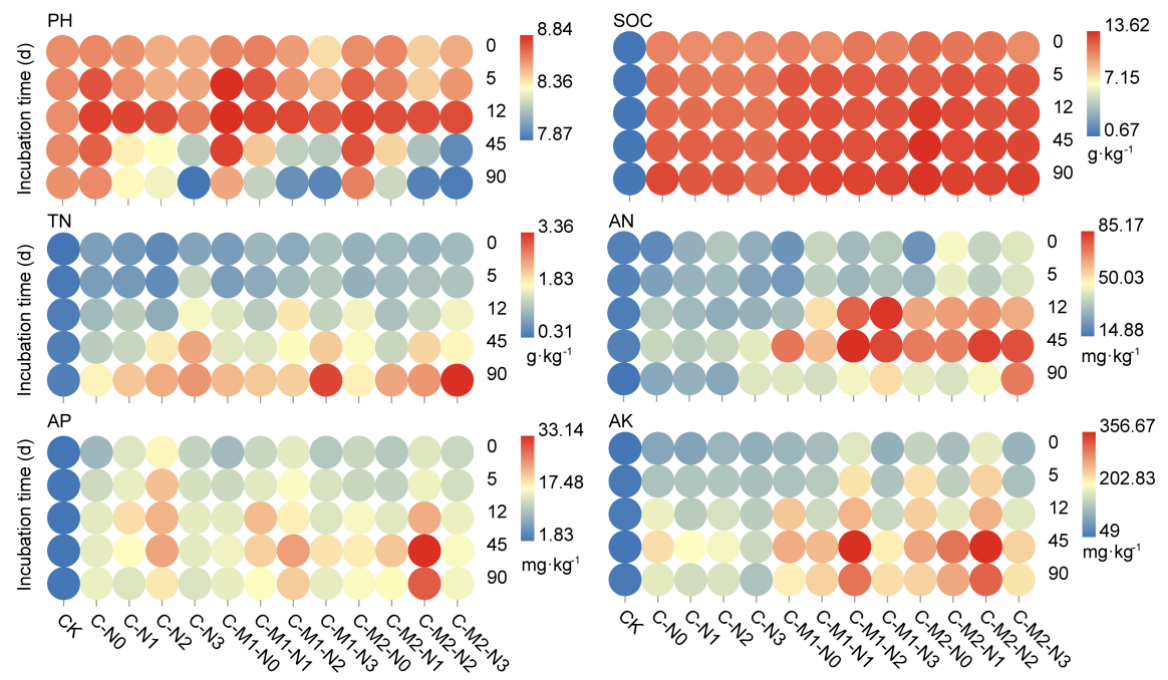

Fig. 2 Heatmap analysis of the relationships between soil physicochemical properties and incubation time in different amended treatments 


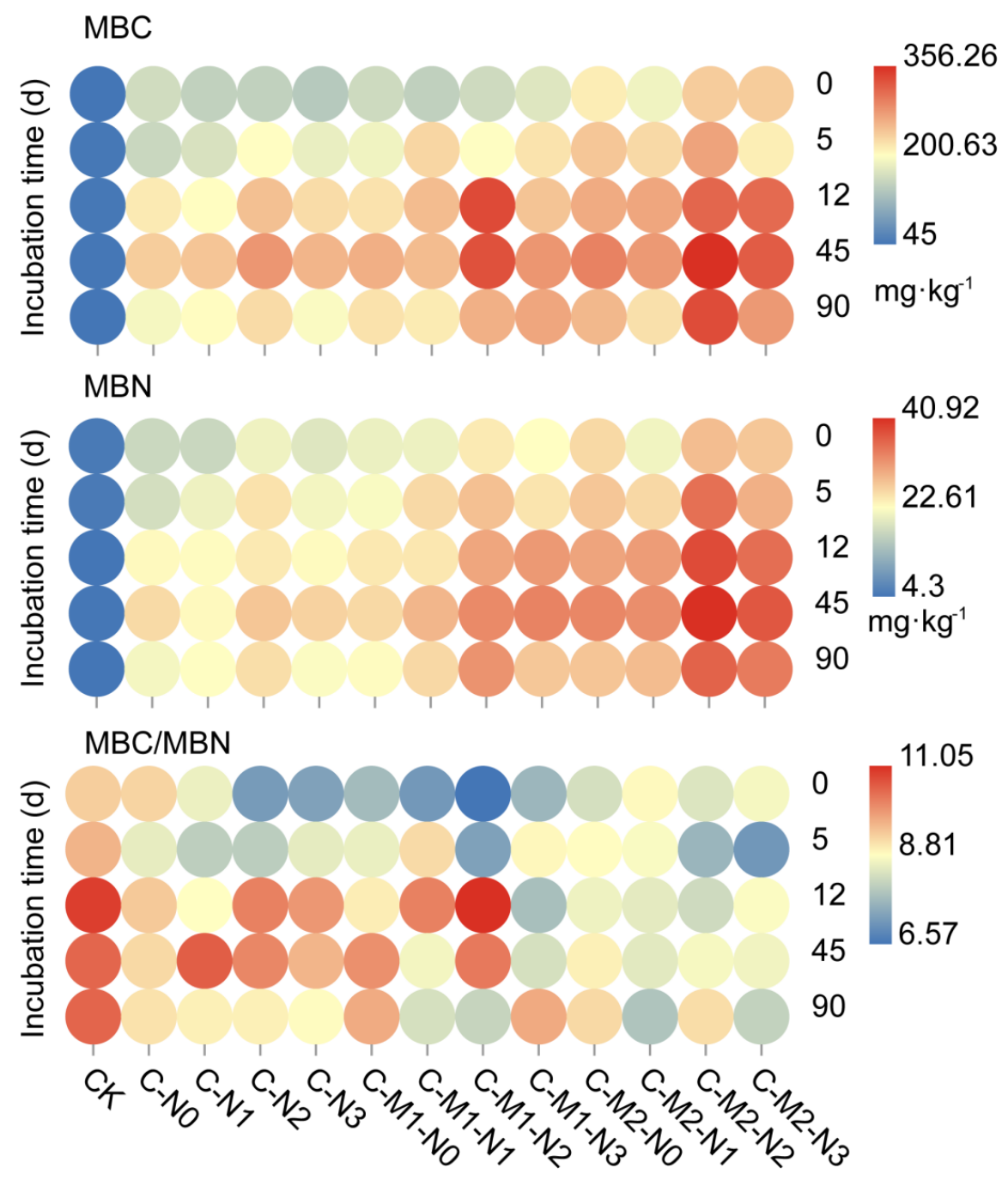

Fig. 3 Heatmap analysis of the relationships between soil microbial biomass and incubation time in different amended treatments
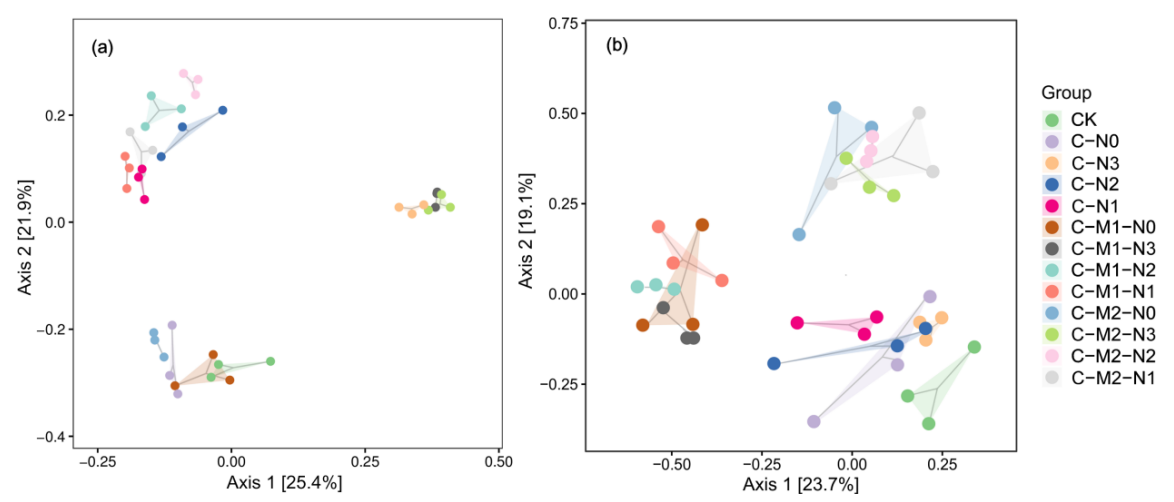

Fig.4 Principal coordinate analysis (PCoA) of bacterial (a) and fungal (b) community composition based on Bray-Curtis distances. Values at axes 1 and 2 are the percentages that can be 
explained by the corresponding axis
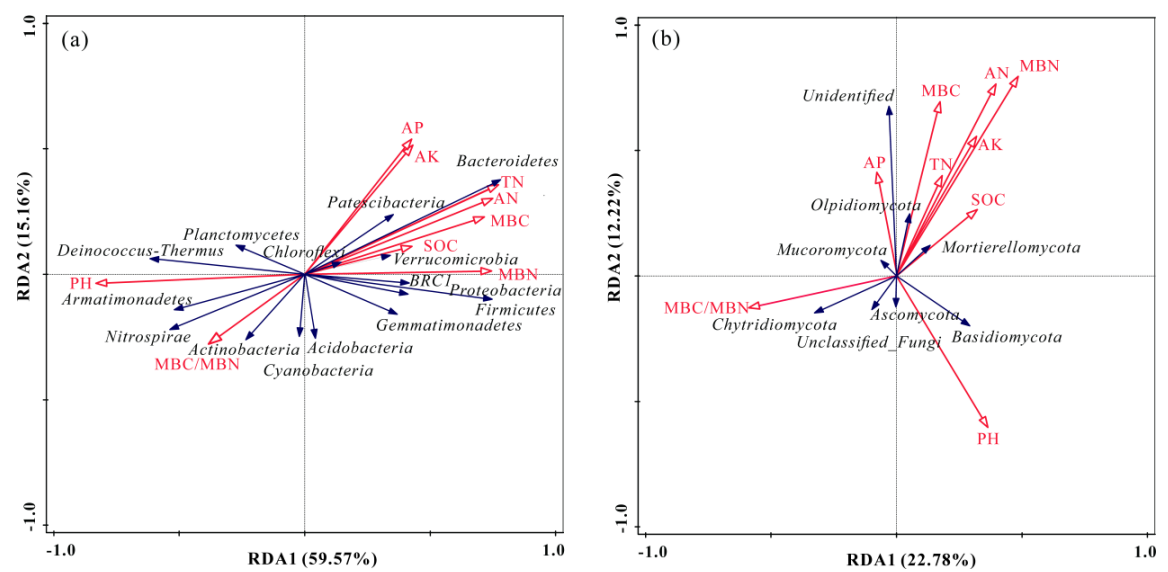

Fig. 5 Redundancy analysis (RDA) identifying the relationships between bacterial (a) and fungal (b) phyla and soil properties in different treatments. Values at axes 1 and 2 are the percentages explained by the corresponding axis

Table list

Table 1 Physicochemical properties in mine soil and biochar amendments (units: $\mathrm{mg} \mathrm{kg}^{-1}$ ). SOC: soil organic carbon, TN: total nitrogen, AN: available nitrogen, AP: available phosphorus, AK: available potassium, $\mathrm{C} / \mathrm{N}$ : soil organic carbon/total nitrogen. $\mathrm{pH}$ and $\mathrm{C} / \mathrm{N}$ were dimensionless units.

Table 2 Soil physicochemical properties and microbial mass in different treatments. Values are means \pm standard error. Different letters indicate significant differences $(P<0.05)$. ${ }^{*} P<0.05$, ${ }^{* *} P<0.01$, ${ }^{* * *} P$ $<0.001$. CK, C, C-N, C-M, C-M-N represent CK, biochar, biochar $+\mathrm{N}$ fertilizer, biochar + microbial agent, biochar $+\mathrm{N}$ fertilizer + microbial agent ( $\mathrm{N}$ fertilizer and microbial agent did not refine to levels)

Table 3 Relative abundance of the dominant bacterial and fungal phyla (relative abundance $>1 \%$ ) in different treatments. Values are means \pm standard error. Different letters indicate significant differences $(\mathrm{P}<0.05) .{ }^{*}$ $P<0.05,{ }^{* *} P<0.01,{ }^{* * *} P<0.001$. CK, C, C-N, C-M, C-M-N represent CK, biochar, biochar $+\mathrm{N}$ fertilizer, biochar + microbial agent, biochar $+\mathrm{N}$ fertilizer + microbial agent $(\mathrm{N}$ fertilizer and microbial agent did not refine to levels)

Table 4 Richness and diversity indices of bacteria (a) and fungal (b) communities in different treatments. Values are means \pm standard error. Different letters indicate significant differences $(\mathrm{P}<0.05) .{ }^{*} P<0.05$, ** $P<0.01,{ }^{* * *} P<0.001$.

Table 1 Physicochemical properties in mine soil and biochar amendments (units: $\mathrm{mg} \mathrm{kg}^{-1}$ ). SOC: soil organic carbon, TN: total nitrogen, AN: available nitrogen, AP: available phosphorus, AK: available potassium, $\mathrm{C} / \mathrm{N}$ : soil organic carbon/total nitrogen. $\mathrm{pH}$ and $\mathrm{C} / \mathrm{N}$ were dimensionless units.

\begin{tabular}{lll}
\hline Property & Mine soil & Biochar \\
pH & 8.50 & 8.35 \\
SOC & 620 & $2.12 \times 10^{5}$ \\
TN & 300 & 6840 \\
C/N & 2.07 & 31.0 \\
AN & 18.23 & 62.71 \\
AP & 1.85 & 127.63 \\
AK & 51.87 & 2970.0
\end{tabular}




\begin{tabular}{lll}
$\mathrm{Cu}$ & 9.92 & - \\
$\mathrm{Zn}$ & 66.7 & - \\
$\mathrm{Pb}$ & 23.5 & - \\
$\mathrm{Cd}$ & 0.21 & - \\
$\mathrm{Cr}$ & 44.9 & - \\
\hline
\end{tabular}

Table 2 Soil physicochemical properties and microbial mass in different treatments. Values are means \pm

standard error. Different letters indicate significant differences $(\mathrm{P}<0.05){ }^{*} \boldsymbol{P}<0.05, * * P<0.01$, *** $\boldsymbol{P}<0.001$. CK, C, C-N, C-M, C-M-N represent CK, biochar, biochar $+\mathrm{N}$ fertilizer, biochar + microbial agent, biochar $+\mathrm{N}$ fertilizer + microbial agent $(\mathrm{N}$ fertilizer and microbial agent did not refine to levels)

\begin{tabular}{llllllll}
\hline Soil properties & CK & C & C-N & C-M & C-M-N & Treatment & Treatment \\
& & & & & & F & P \\
pH & $8.64 \pm 0.01 \mathrm{a}$ & $8.71 \pm 0.02 \mathrm{a}$ & $8.47 \pm 0.04 \mathrm{~b}$ & $8.72 \pm 0.02 \mathrm{a}$ & $8.44 \pm 0.02 \mathrm{~b}$ & 37.03 & $* * *$ \\
SOC & $0.71 \pm 0.01 \mathrm{c}$ & $11.92 \pm 0.17 \mathrm{~b}$ & $11.56 \pm 0.09 \mathrm{~b}$ & $12.57 \pm 0.14 \mathrm{a}$ & $12.40 \pm 0.08 \mathrm{a}$ & 4277.37 & $* * *$ \\
$\mathrm{TN}$ & $0.37 \pm 0.01 \mathrm{c}$ & $1.15 \pm 0.12 \mathrm{~b}$ & $1.45 \pm 0.76 \mathrm{a}$ & $1.44 \pm 2.31 \mathrm{a}$ & $1.63 \pm 2.71 \mathrm{a}$ & 59.79 & $* * *$ \\
$\mathrm{AN}$ & $17.38 \pm 0.30 \mathrm{~d}$ & $29.86 \pm 2.16 \mathrm{c}$ & $33.18 \pm 0.93 \mathrm{c}$ & $43.28 \pm 3.63 \mathrm{~b}$ & $55.16 \pm 1.88 \mathrm{a}$ & 129.34 & $* * *$ \\
$\mathrm{AP}$ & $1.90 \pm 0.01 \mathrm{c}$ & $13.79 \pm 0.83 \mathrm{~b}$ & $17.37 \pm 0.61 \mathrm{a}$ & $14.81 \pm 0.53 \mathrm{~b}$ & $17.75 \pm 0.61 \mathrm{a}$ & 55.09 & $* * *$ \\
$\mathrm{AK}$ & $51.65 \pm 0.61 \mathrm{c}$ & $166.48 \pm 12.36 \mathrm{~b}$ & $148.63 \pm 5.03 \mathrm{~b}$ & $210.09 \pm 10.21 \mathrm{a}$ & $212.23 \pm 7.63 \mathrm{a}$ & 70.66 & $* * *$ \\
$\mathrm{MBC}$ & $49.2 \pm 0.77 \mathrm{~d}$ & $192.64 \pm 8.88 \mathrm{c}$ & $204.54 \pm 6.52 \mathrm{c}$ & $231.73 \pm 7.66 \mathrm{~b}$ & $254.34 \pm 6.87 \mathrm{a}$ & 88.57 & $* * *$ \\
$\mathrm{MBN}$ & $5.15 \pm 0.12 \mathrm{~d}$ & $21.25 \pm 1.00 \mathrm{c}$ & $22.86 \pm 0.45 \mathrm{c}$ & $26.10 \pm 0.76 \mathrm{~b}$ & $29.93 \pm 0.58 \mathrm{a}$ & 162.93 & $* * *$ \\
MBC/MBN & $9.60 \pm 0.16 \mathrm{a}$ & $9.10 \pm 0.19 \mathrm{a}$ & $8.89 \pm 0.17 \mathrm{a}$ & $8.89 \pm 0.18 \mathrm{a}$ & $8.50 \pm 0.16 \mathrm{~b}$ & 3.67 & $* *$ \\
\hline
\end{tabular}

Table 3 Relative abundance of the dominant bacterial and fungal phyla (relative abundance $>1 \%)$ in different treatments. Values are means \pm standard error. Different letters indicate significant differences $(\mathrm{P}<0.05) .{ }^{*} P<0.05, * * P<0.01, * * * P<0.001$. CK, C, C-N, C-M, C$\mathrm{M}-\mathrm{N}$ represent $\mathrm{CK}$, biochar, biochar $+\mathrm{N}$ fertilizer, biochar + microbial agent, biochar $+\mathrm{N}$ fertilizer + microbial agent ( $\mathrm{N}$ fertilizer and microbial agent did not refine to levels)

\begin{tabular}{llllllll}
\hline \multirow{3}{*}{ Bacteria } & Taxon & CK & C & C-N & C-M & C-M-N & P \\
& Proteobacteria & $73.98 \pm 14.44 \mathrm{a}$ & $62.69 \pm 4.72 \mathrm{ab}$ & $67.14 \pm 2.32 \mathrm{ab}$ & $70.81 \pm 5.99 \mathrm{a}$ & $59.83 \pm 1.77 \mathrm{~b}$ & 0.093 \\
& Actinobacteria & $11.19 \pm 8.27 \mathrm{a}$ & $14.78 \pm 2.61 \mathrm{a}$ & $13.62 \pm 1.54 \mathrm{a}$ & $8.33 \pm 2.43 \mathrm{a}$ & $10.84 \pm 0.66 \mathrm{a}$ & 0.296 \\
& Bacteroidetes & $4.98 \pm 1.23 \mathrm{~b}$ & $6.03 \pm 0.67 \mathrm{~b}$ & $8.88 \pm 0.83 \mathrm{~b}$ & $6.3 \pm 0.89 \mathrm{~b}$ & $12.91 \pm 0.98 \mathrm{a}$ & $* * *$ \\
& Gemmatimonadetes & $2.31 \pm 1.39 \mathrm{~b}$ & $4.21 \pm 0.94 \mathrm{ab}$ & $3.72 \pm 0.35 \mathrm{ab}$ & $3.26 \pm 0.80 \mathrm{ab}$ & $5.15 \pm 0.54 \mathrm{a}$ & 0.091 \\
& Acidobacteria & $1.37 \pm 0.88 \mathrm{c}$ & $2.72 \pm 0.81 \mathrm{a}$ & $0.38 \pm 0.10 \mathrm{~b}$ & $1.85 \pm 0.48 \mathrm{ac}$ & $0.25 \pm 0.05 \mathrm{~b}$ & $* * *$ \\
& Chloroflexi & $1.89 \pm 1.23 \mathrm{ab}$ & $2.32 \pm 0.49 \mathrm{ab}$ & $1.03 \pm 0.09 \mathrm{~b}$ & $3.05 \pm 1.15 \mathrm{a}$ & $1.8 \pm 0.19 \mathrm{ab}$ & 0.102 \\
& Patescibacteria & $1.23 \pm 0.59 \mathrm{~b}$ & $5.17 \pm 2.75 \mathrm{a}$ & $2.22 \pm 0.51 \mathrm{~b}$ & $1.7 \pm 0.33 \mathrm{~b}$ & $1.93 \pm 0.40 \mathrm{~b}$ & 0.075 \\
& Firmicutes & $0.76 \pm 0.16 \mathrm{~b}$ & $0.85 \pm 0.31 \mathrm{~b}$ & $1.85 \pm 0.68 \mathrm{~b}$ & $2.91 \pm 0.69 \mathrm{~b}$ & $4.8 \pm 0.63 \mathrm{a}$ & $0.003^{* *}$ \\
Fungal & Ascomycota & $79.06 \pm 1.78 \mathrm{a}$ & $85.66 \pm 4.46 \mathrm{a}$ & $81.53 \pm 3.97 \mathrm{a}$ & $71.381 \pm 6.32 \mathrm{a}$ & $69.17 \pm 4.13 \mathrm{a}$ & 0.196 \\
& unclassified_Fungi & $6.91 \pm 1.82 \mathrm{a}$ & $7.61 \pm 1.03 \mathrm{a}$ & $10.42 \pm 4.25 \mathrm{a}$ & $10.9 \pm 4.81 \mathrm{a}$ & $10.22 \pm 1.66 \mathrm{a}$ & 0.77 \\
& Basidiomycota & $6.55 \pm 1.04 \mathrm{a}$ & $4.07 \pm 0.34 \mathrm{a}$ & $4.77 \pm 1.39 \mathrm{a}$ & $13.58 \pm 6.20 \mathrm{a}$ & $9.45 \pm 4.52 \mathrm{a}$ & 0.798 \\
& unidentified & $3.15 \pm 0.8 \mathrm{~b}$ & $6.04 \pm 2.93 \mathrm{ab}$ & $2.48 \pm 0.93 \mathrm{~b}$ & $3.02 \pm 0.57 \mathrm{~b}$ & $10.53 \pm 1.70 \mathrm{a}$ & $\mathbf{0 . 0 0 5}$ \\
& Chytridiomycota & $2.93 \pm 2.93 \mathrm{a}$ & $0.2 \pm 0.18 \mathrm{~b}$ & $0.09 \pm 0.09 \mathrm{~b}$ & $0.15 \pm 0.11 \mathrm{~b}$ & $0.07 \pm 0.06 \mathrm{~b}$ & $\mathbf{0 . 0 1 6}$ \\
\hline
\end{tabular}

Table 4 Richness and diversity indices of bacteria (a) and fungal (b) communities in different treatments. Values are means \pm standard error. Different letters indicate significant differences 
$(\mathrm{P}<0.05)$.

\begin{tabular}{|c|c|c|c|c|c|c|}
\hline & Bacteria & Bacteria & Bacteria & Fungi & Fungi & Fungi \\
\hline Treatments & Chao1 & Simpson & Shannon & Chao1 & Simpson & Shannon \\
\hline CK & $624.22 \pm 254.92 \mathrm{e}$ & $0.81 \pm 0.1 b$ & $5.25 \pm 1.52 \mathrm{~b}$ & $50.03 \pm 7.48 \mathrm{e}$ & $0.85 \pm 0.02 \mathrm{a}$ & $3.76 \pm 0.15 b$ \\
\hline $\mathrm{C}-\mathrm{N} 0$ & $877.43 \pm 11.76 \mathrm{bcd}$ & $0.97 \pm 0.02 \mathrm{a}$ & $7.91 \pm 0.52 \mathrm{a}$ & $139.13 \pm 28.19 \mathrm{~cd}$ & $0.92 \pm 0.004 a$ & $4.73 \pm 0.17 \mathrm{ab}$ \\
\hline $\mathrm{C}-\mathrm{N} 1$ & $639.1 \pm 56.42 \mathrm{e}$ & $0.98 \pm 0.003 \mathrm{a}$ & $7.49 \pm 0.10 \mathrm{a}$ & $91.30 \pm 3.31 \mathrm{de}$ & $0.9 \pm 0.006 \mathrm{a}$ & $3.99 \pm 0.06 \mathrm{ab}$ \\
\hline $\mathrm{C}-\mathrm{N} 2$ & $1045.32 \pm 38.75 \mathrm{ab}$ & $0.98 \pm 0.003 \mathrm{a}$ & $7.51 \pm 0.16 \mathrm{a}$ & $73.95 \pm 16.67 \mathrm{e}$ & $0.93 \pm 0.03 \mathrm{a}$ & $4.06 \pm 0.29 \mathrm{ab}$ \\
\hline $\mathrm{C}-\mathrm{N} 3$ & $740.89 \pm 111.03 \mathrm{de}$ & $0.98 \pm 0.004 \mathrm{a}$ & $7.33 \pm 0.27 \mathrm{a}$ & $54.65 \pm 5.42 \mathrm{e}$ & $0.94 \pm 0.004 a$ & $4.50 \pm 0.07 \mathrm{ab}$ \\
\hline C-M1-N0 & $873.89 \pm 30.20 \mathrm{~cd}$ & $0.94 \pm 0.05 \mathrm{a}$ & $7.23 \pm 0.83 \mathrm{a}$ & $58.84 \pm 10.82 \mathrm{e}$ & $0.86 \pm 0.02 \mathrm{a}$ & $3.79 \pm 0.06 \mathrm{~b}$ \\
\hline C-M1-N1 & $804.79 \pm 14.26 \mathrm{~cd}$ & $0.99 \pm 0.0008 \mathrm{a}$ & $7.88 \pm 0.05 \mathrm{a}$ & $107.45 \pm 27.89 \mathrm{de}$ & $0.88 \pm 0.03 \mathrm{a}$ & $4.14 \pm 0.40 \mathrm{ab}$ \\
\hline C-M1-N2 & $1080.22 \pm 126.82 \mathrm{ab}$ & $0.99 \pm 0.001 \mathrm{a}$ & $7.96 \pm 0.05 \mathrm{a}$ & $102.69 \pm 7.93 \mathrm{de}$ & $0.94 \pm 0.008 \mathrm{a}$ & $5.25 \pm 0.26 \mathrm{a}$ \\
\hline C-M1-N3 & $720.54 \pm 150.13 \mathrm{e}$ & $0.99 \pm 0.001 \mathrm{a}$ & $7.58 \pm 0.06 \mathrm{a}$ & $105.47 \pm 1.97 \mathrm{de}$ & $0.96 \pm 0.019 a$ & $4.89 \pm 0.16 \mathrm{ab}$ \\
\hline C-M2-N0 & $903.53 \pm 49.69 \mathrm{abc}$ & $0.99 \pm 0.002 \mathrm{a}$ & $7.57 \pm 0.07 \mathrm{a}$ & $308.23 \pm 26.87 \mathrm{a}$ & $0.88 \pm 0.04 \mathrm{a}$ & $4.56 \pm 0.24 \mathrm{ab}$ \\
\hline C-M2-N1 & $874.41 \pm 16.28 \mathrm{bcd}$ & $0.99 \pm 0.003 \mathrm{a}$ & $7.54 \pm 0.21 \mathrm{a}$ & $170.49 \pm 20.52 \mathrm{c}$ & $0.91 \pm 0.03 \mathrm{a}$ & $4.77 \pm 0.62 \mathrm{ab}$ \\
\hline $\mathrm{C}-\mathrm{M} 2-\mathrm{N} 2$ & $1233.68 \pm 46.97 \mathrm{a}$ & $0.99 \pm 0.004 a$ & $7.59 \pm 0.06 \mathrm{a}$ & $233.08 \pm 39.81 b$ & $0.95 \pm 0.02 \mathrm{a}$ & $5.58 \pm 0.32 \mathrm{a}$ \\
\hline C-M2-N3 & $854.47 \pm 6.21 \mathrm{~cd}$ & $0.98 \pm 0.003 \mathrm{a}$ & $7.5 \pm 0.18 \mathrm{a}$ & $106.32 \pm 30.47 \mathrm{de}$ & $0.94 \pm 0.008 \mathrm{a}$ & $4.89 \pm 0.08 \mathrm{ab}$ \\
\hline
\end{tabular}

